\title{
Morphological, molecular and developmental characterization of the thelastomatid nematode Thelastoma bulhoesi (de Magalhães, 1900) (Oxyuridomorpha: Thelastomatidae) parasite of Periplaneta americana (Linnaeus, 1758) (Blattodea: Blattidae) in Japan
}

\section{Sota Ozawa ${ }^{\text {*** }}$, Jans Morffe ${ }^{2 * *}$, Cláudia S.L. Vicente ${ }^{1,3}$, Kenji Ikeda1, Ryoji Shinya ${ }^{4}$ and Koichi Hasegawa ${ }^{*}$}

\begin{abstract}
${ }^{1}$ Department of Environmental Biology, College of Bioscience \& Biotechnology, Chubu University. 1200 Matsumoto, Kasugai, Aichi 487-8501 Japan; ${ }^{2}$ Instituto de Ecología y Sistemática, Carretera Varona 11835 e/ Oriente y Lindero, La Habana 19, CP 11900, Calabazar, Boyeros, La Habana, Cuba; ${ }^{3}$ ICAAM - Instituto de Ciências Agrárias e Ambientais Mediterrânicas, Departamento de Biologia, Universidade de Évora, Núcleo da Mitra, Ap. 94, 7002-554 Évora, Portugal; ${ }^{4} \mathrm{HHMI}$ and Division of Biology and Biological Engineering, California Institute of Technology, 1200 East California Blvd, Pasadena, CA 91125, USA
\end{abstract}

\begin{abstract}
The American cockroach Periplaneta americana (Linnaeus, 1758) (Blattodea: Blattidae) has been spreading worldwide by commerce and has successfully adjusted to living with humans. There are many reports of thelastomatid parasitic nematode isolated from P. americana in many countries including USA, Canada, India, Argentina, Bulgaria, but not in Japan. We have investigated the parasitic nematodes in P. americana lab strain and field-captured individuals in Japan and found that Thelastoma bulhoesi (de Magalhães, 1900) (Oxyuridomorpha: Thelastomatidae) parasitizes with high infection rates. We described morphological, molecular, and developmental characters of the parasitic nematode because such information was missing despite it has been discovered more than one hundred years ago. We described morphometrics with DIC microscopy and fine structure of male and female adult with SEM observation. We also reveal the embryonic and postembryonic development of this nematode. This is the first report of a thelastomatid nematode isolated from American cockroach in Japan, and the data showed here is also very useful and fundamental for further analysis of the cockroach and parasite relations.
\end{abstract}

\section{Keywords}

Thelastoma bulhoesi, American cockroach, taxonomy, systematics, embryogenesis, post-embryogenesis

\section{Introduction}

Cockroaches are referred as "living fossils" with about 350million-years history and constitute one of the most diverse groups of insects with about 4,500 species that inhabit the most diverse environments on Earth (Rentz 2014). In addition, several species of cockroaches, mainly the American cockroach Periplaneta americana (Linnaeus, 1758), smokybrown cockroach P. fuliginosa (Serville, 1839), and German cockroach Blattella germanica (Linnaeus, 1767) have ex- tremely high environmental adaptability and are now spreading and inhabiting around the world by the modern human economic activities, being considered as one of the most serious urban sanitary pests (Appel and Smith 2002; Bell et al. 2007).

P. americana has spread worldwide by commerce and successfully adjusted to living with humans (Bell and Adiyodi, 1981). In Japan, this cockroach has mainly inhabited in Okinawa islands, but their colonization has also been confirmed in Kyushu, Shikoku, Honshu and Hokkaido (The Japanese So-

*Corresponding author: koichihasegawa@isc.chubu.ac.jp;

**These authors contributed equally as first author 
ciety of Pestology 2014). Despite of thelastomatid parasitic nematodes have been found in many species of cockroaches, there is no report about parasitic nematodes in P. americana in Japan. Thelastomatid nematodes parasitizing $P$. americana in the USA and Canada were Thelastoma bulhoesi (de Magalhães, 1900), T. periplaneticola (Leibersperger, 1960); Hammerschmidtiella diesingi (Hammerschmidt, 1838), Leidynema appendiculatum (Leidy, 1850) (Chitwood 1932; Dobrovolny and Ackert 1934; Hominick and Davey 1972; McCallister 1988; Adamson and Noble 1993; Connor and Adamson 1998). These species are commonly reported in lab cultured $P$. americana. In other countries, more divergence of Hammerschmidtiella species were reported: $H$. diesingi, $H$. aspiculus Biswas and Chakravarty, 1963; H. bisiri Singh and Kaur, 1988; H. indicus Singh and Malti, 2003, and L. appendiculatum in India (Biswas and Chakravarty 1963; Singh and Kaur 1988; Shah 2007; Chaudhary et al. 2014), H. diesingi and H. laplatae Camino, Ricuzzi and Costa, 2013 in Argentina (Blanco et al. 2012; Camino et al. 2013), and H. diesingi and L. appendiculatum in Bulgaria (Nedelchev et al. 2013). The parasitic nematode species in P. americana are seemingly different in different locations, but the most frequently reported were $H$. diesingi and L. appendiculatum.

In the thelastomatids from P. americana, T. bulhoesi is one of the most studied. In addition to the original description from Brazil (de Magalhães 1900), the species have been recorded from the same host from North America (Chitwood 1932). As a common parasite in laboratory cultures of $P$. americana (Adamson and Van Waerebeke 1992), several aspects of the biology and development of this nematode have been studied (McCallister and Schmidt 1981, 1983, 1984, McCallister 1988, 1993; Adamson and Clease 1989). Also, T. bulhoesi was recorded from Blatta orientalis (Linnaeus, 1758) from the former Republic of Czechoslovakia (Groschaft 1956) and from two millipede hosts: Gymnostreptus sp. and Neptunobolus hogei Schubart, 1949 from Brazil (Dollfus 1952; Ruiz and Coelho 1955).

Even though with such a long research history, reports of morphological and molecular features of $T$. bulhoesi are still missing. Therefore, we show here the morphology, molecular and developmental information about $T$. bulhoesi isolated from $P$. americana laboratory strain and wild individuals captured in Okinawa Islands, Japan. We also reveal the embryonic and postembryonic development of this nematode. This is the first report of a thelastomatid nematode isolated from the American cockroach in Japan, and the data showed here are also very useful as fundamentals for our further analysis of the cockroach and parasite relations.

\section{Materials and Methods}

\section{Cockroach strain and rearing}

P. americana $\mathrm{NC}$ strain was used in this experiment. This strain was provided by the Nissan Chemical Industries, LTD, and maintained in the Hasegawa laboratory, Chubu University, Japan for three years following the method described by Ozawa et al. (2014). Nematode-free P. americana strain was established as follows: many oothecae oviposited from P. americana $\mathrm{NC}$ strain were collected, surface-cleaned with ethanol and kept in a plastic dish until larval hatching. Hatched larvae were transferred into a plastic cage and reared. Some individuals of the established nematode-free strain were often dissected to confirm that they were all free from any thelastomatid parasitic nematodes.

To study the parasitic nematodes in the field, cockroach $P$. americana were caught by hand in the Ishigaki Island, Okinawa, Japan, and stored individually in plastic film cases with humid tissue paper until dissection. We collected a total of six individuals of $P$. americana from three independent points of Ishigaki city, Okinawa prefecture: one adult cockroach was captured in Nagura in 2013; one adult male and adult female, and two juveniles were collected in Okawa in 2013; and one juvenile was picked in Okawa in 2014.

\section{Nematode observation}

In total 97 American cockroaches of the lab culturing strain $\mathrm{NC}$ were dissected and checked for the existence of parasitic nematodes. The extracted cockroach hindgut was placed in Syracuse watch glasses containing cockroach Ringer's solution $\left(\mathrm{NaCl} 9.32 \mathrm{~g}, \mathrm{KCl} 0.77 \mathrm{~g}, \mathrm{NaHCO}_{3} 0.18\right.$ $\mathrm{g}$; $\mathrm{NaH}_{2} \mathrm{PO}_{4} 0.01 \mathrm{~g}, \mathrm{CaCl}_{2} 0.5 \mathrm{~g}$ in $1 \mathrm{~L}$ of distilled water) (Bell 1981) and split longitudinally with tweezers to release nematodes. Nematode species, sex and stage were observed under stereomicroscope (SMZ600, Nikon, Japan). Nematodes were then picked with a mouth pipette, transferred onto an agar pad (Shaham 2006), covered and sealed with a silicon grease-rimmed coverslip for viewing by Nomarski DIC optics (Eclipse E600, Nikon). For morphometrics, nematodes were transferred with a mouth pipette into an agar pad with hole (Ozawa et al. 2014), gently heat-killed, covered with coverslips and measured by micrometer. De Manian indexes a, b, c and V\% were also calculated. DIC micrographs were captured with cooled CCD camera VTCH1.4ICE (Visualix, Japan) with a software IS capture (Visualix, Japan). Line drawings were made with the softwares CorelDRAW X3 and Adobe Photoshop CS2 using the micrographs as templates.

For permanent mounts, nematodes were first fixed with TAF ( $2 \%$ Triethanolamine and $7.5 \%$ Formaldehyde), dehydrate with slow evaporation method and mounted on a slide (Morffe and García 2010). The studied material is deposited in the Nematological Collection of Hasegawa Laboratory (NCHL), Chubu University, Japan and the Helminthological Collection of the Zoological Collections (CZACC), Instituto de Ecología y Sistemática, Havana, Cuba.

For SEM observation, nematodes were pre-fixed with $4 \%$ formaldehyde $/ 2 \%$ glutaraldehyde (in $0.1 \mathrm{M}$ phosphate buffer, $\mathrm{pH} 6.0$ ), post-fixed with $2 \%$ osmium tetroxide, de- 
hydrated sequentially with ethanol $(30 \%, 50 \%, 70 \%, 90 \%$, $95 \%, 100 \% \times 2 / 30 \mathrm{~min}$ each), and dried with t-butanol using freeze dryer (ES-2030, Hitachi, Japan). Nematodes were then mounted on a double sticky aluminum tape on a stage, sputter coated with gold using a sputter coater (E-1030, Hitachi), and observed with the scanning electron microscope (JSM-6510LA, JEOL, Japan) at $15 \mathrm{kV}$ accelerating voltage.

\section{Molecular phylogenetic analysis}

Genomic DNA was extracted from individual adult nematode females with Qiagen DNeasy Blood and Tissue Kit (Qiagen, USA). The D2/D3 expansion segment of 28S ribosomal RNA gene (D2/D3 LSU) was amplified and sequenced using the universal primers D2a 5' - ACA AGT ACC GTG AGG GAA AGT TG -3' and D3b 5'-TCG GAA GGA ACC AGC TAC TA -3' (Nunn 1992). Obtained sequences were submitted to BLASTN search (NCBI, National Centre of Biotechnology and Information, http://www.ncbi.nlm.nih.gov/) for significant nucleotide sequence alignments and to GenBank for assignment of an accession number.

For the phylogenetic analysis, the published sequences of D2/D3 segment in Thelastoma, Hammerschmidtiella, and Leidynema were obtained and performed multiple sequence alignment using ClustalW through the BioEdit interface (version 5.0.9) (Hall 1999). Pairwise comparisons of the \% differences (D) between each sequence combination were performed using the formula $\mathrm{D}=(\mathrm{M} / \mathrm{L}) \times 100$ (Chilton et al . $1995)$, where $M$ is the number of alignment positions at which the two sequences have a base in common, and $\mathrm{L}$ is the total number of alignment positions. Phylogeny tree was constructed from evolutionary distances using the Neighbor-Joining (NJ) method (Saitou and Nei 1987) and Kimura's two-parameter model (Kimura 1980) with a gamma distribution, using the Mega 5.0 software (Tamura et al. 2011). Ascaris lumbricoides AY210806 was selected as outgroup in the analysis. Phylogenetic robustness was inferred by bootstrap analysis using 1000 iterations (Felsenstein 1985).

\section{Observation of $T$. bulhoesi embryogenesis}

When nematode adult female was transferred into the Cockroach Ringer's solution, many eggs were laid within thirty minutes. To observe the embryogenesis of T. bulhoesi, justlaid eggs were picked-up with a mouth pipette and transferred onto an agar pad. This time-point was set as zero hour for embryogenesis observation. Total eight 1-cell embryos were collected and images were acquired at room temperature (around $25^{\circ} \mathrm{C}$ ) with DIC microscopy for every hour until the 4-cell stage, and then for every 24 hours until the L2 stage. We determined the hour or days (average \pm S.D., $\mathrm{N}=8$ ) necessary from 1-cell stage to become 2-cell stage, 4-cell stage, L1 stage, and L2 stage.

\section{Morphological observation of T. bulhoesi at each postem- bryonic stage}

To observe the postembryonic development of T. bulhoesi, artificial infections were performed with the nematode-free $P$. americana. Eggs were obtained from the gravid females of T. bulhoesi and kept in the Cockroach Ringer's solution for 12 days at $25^{\circ} \mathrm{C}$ until all reached the $\mathrm{L} 2$ resting stage. Cockroach instars (body length $19-20 \mathrm{~mm}$ ) were fasted for three days before artificial infection. Three groups of ten fasted cockroaches were reared in cylindrical plastic cases $(130 \mathrm{~mm}$ diameter $\times 225 \mathrm{~mm}$ height $)$ with $0.4 \mathrm{~g}$ of the bait (Ozawa et al. 2014) mixed with about 500 of the L2 resting stage nematode eggs. During the rest of the experiment, cockroaches were fed with bait without nematode eggs ad libitum. One cockroach of each group was dissected after 1, 3, $7,14,21,31$ and 41 days to observe the nematode morphology.

\section{Results}

A total of 97 American cockroaches of the lab culturing strain $\mathrm{NC}$ were dissected and confirmed the high infection $\%$ of T. bulhoesi; infection \% in cockroach adult male was $80 \%$ $(\mathrm{N}=16)$, adult female was $91 \%(\mathrm{~N}=23)$, and juvenile was $93 \%(\mathrm{~N}=58)$. Total six American cockroaches captured in the field were infected by $T$. bulhoesi with $100 \%$ (adult male $\mathrm{N}=2$, adult female $\mathrm{N}=1$, juvenile $\mathrm{N}=3$ ).

\section{Systematics}

Family Thelastomatidae Travassos, 1929

Thelastoma Leidy, 1849

Thelastoma bulhoesi (de Magalhães, 1900)

Figs. 1 A-F, 2 A-F, 3 A-H, 4 A-E

\section{Studied material}

Vouchers $2 q q$, in Periplaneta americana NC strain; Kasugai, Aichi, Japan; 29/IV/2015; Sota Ozawa coll.; Hasegawa laboratory, Chubu University NCHL-A1, -A2. $2 \hat{\jmath} \hat{\jmath}$, same data as the latter; Hasegawa Laboratory, Chubu University NCHLA3, -A4. ㅇ, same data as the latter; CZACC 11.5100. $\widehat{\jmath}$, same

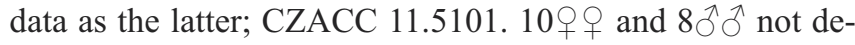
posited in collection.

\section{Measurements}

Based on ten females and eight males mounted on agar pad with hole and three females and three males permanently mounted in glycerine (see Table I).

\section{Re-description}

Female. Body relatively robust, widening from the base of the first cephalic annule, maximum body width at level of the 

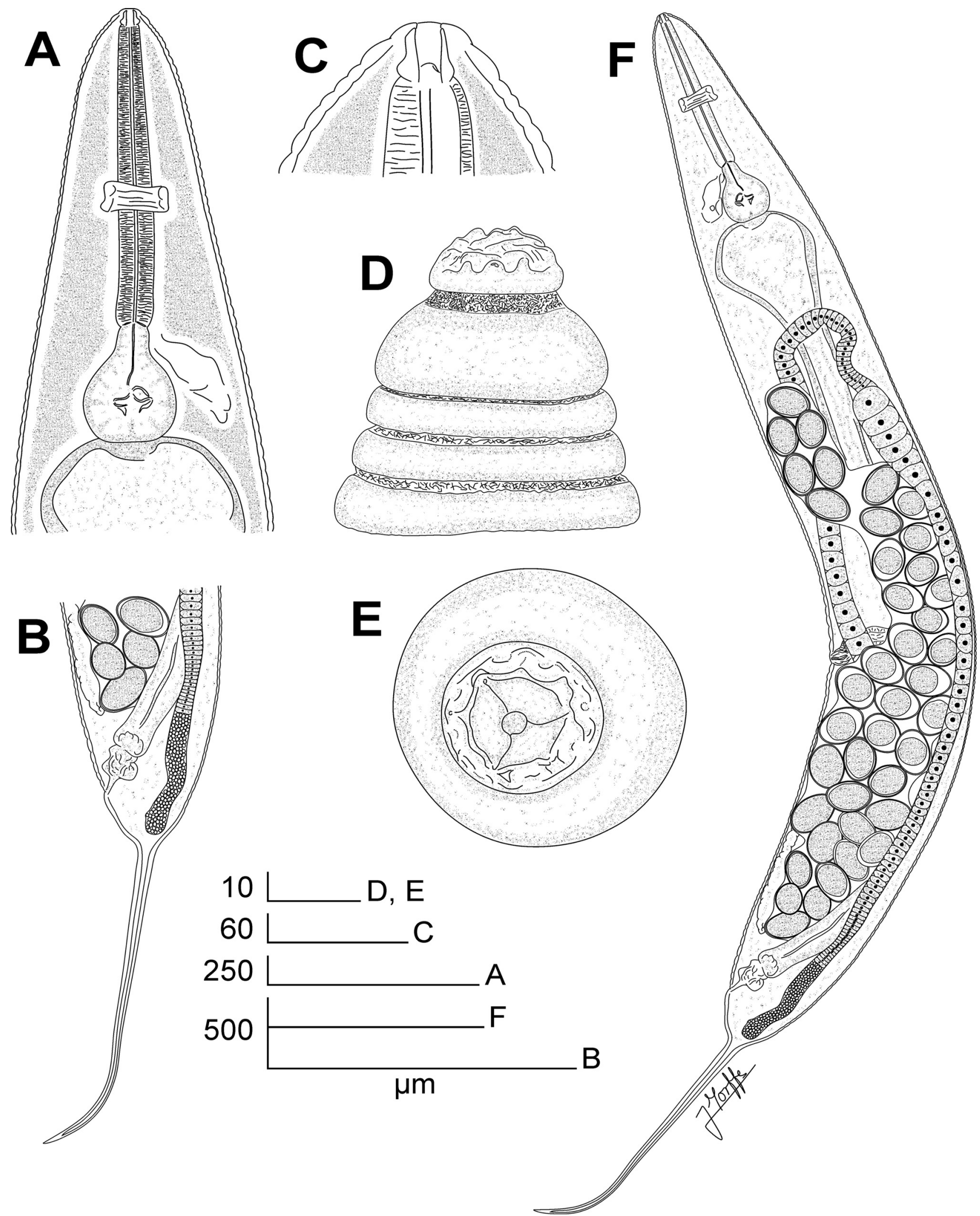

Fig. 1. Thelastoma bulhoesi (de Magalhães, 1900). Female. A. Oesophageal region, ventrolateral view. B. Tail, lateral view. C. Anterior end, optical section. D. Anterior end, external, lateral view (reconstructed from SEM image). E. Anterior end, en face view (reconstructed from SEM image). F. Habitus, ventrolateral view 


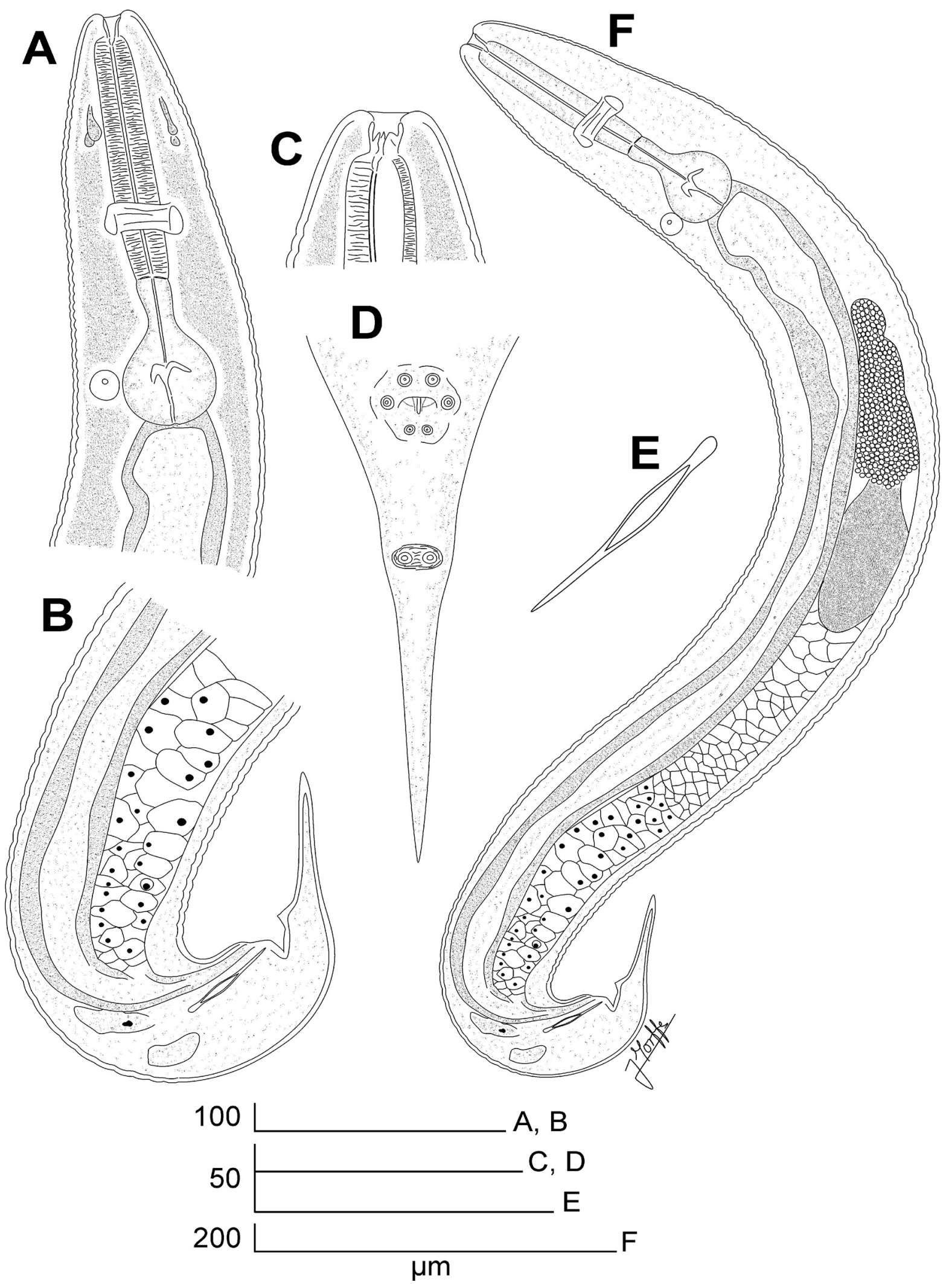

Fig. 2. Thelastoma bulhoesi (de Magalhães, 1900). Male. A. Oesophageal region, ventro-lateral view. B. Tail, lateral view. C. Anterior end, optical section. D. Tail, ventral view. E. Spicule. F. Habitus, ventrolateral view 

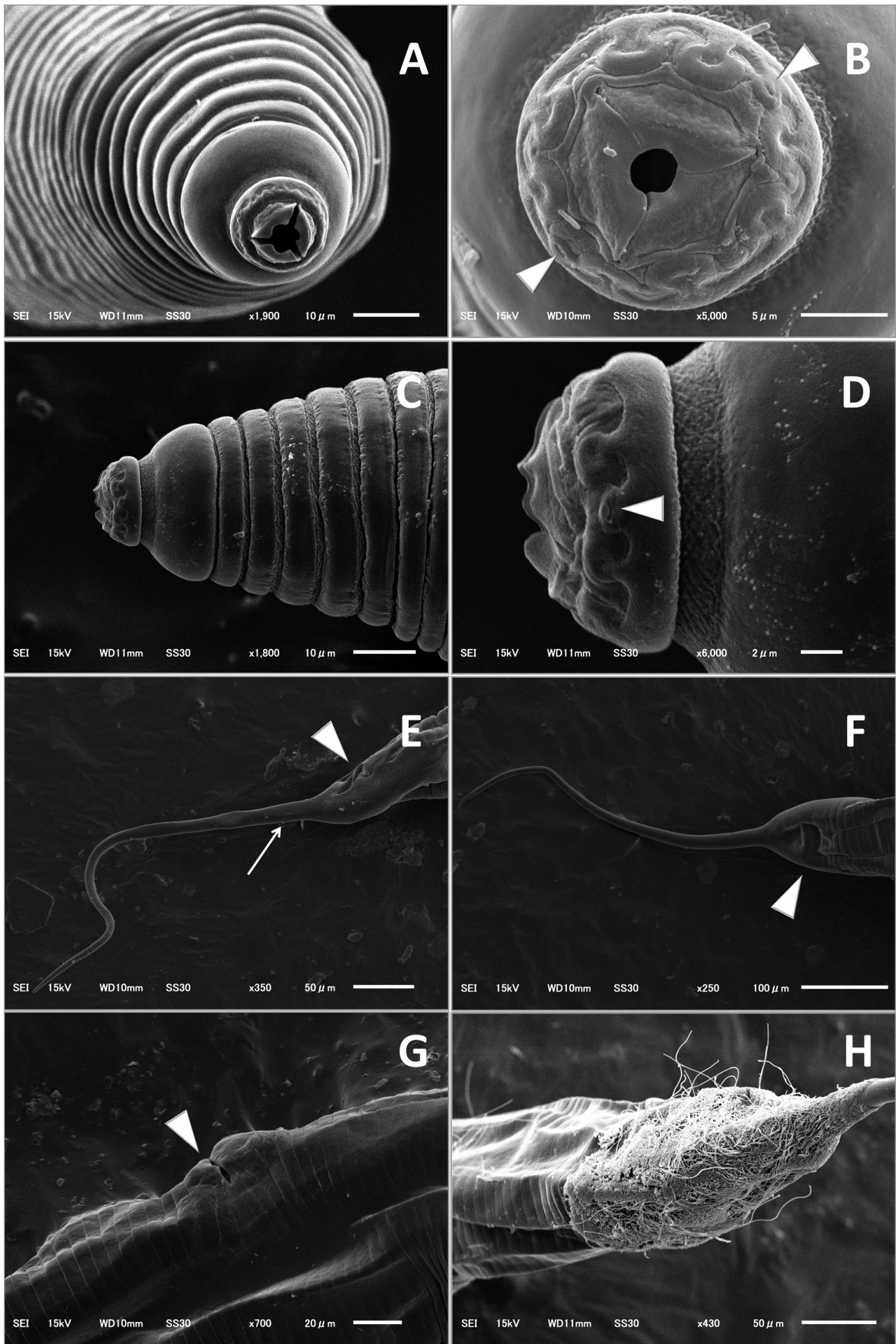

Fig. 3. Thelastoma bulhoesi (de Magalhães, 1900). Female. SEM images. A. Cephalic region with mouth opening, en face view. B. Detail of cephalic region, en face view (white arrowheads indicate the amphidial sensory pore). C. Cephalic region, lateral view. D. Detail of cephalic region, lateral view (white arrowheads indicate the amphidial sensory pores). E. Tail region, lateral view (white arrowhead indicates the anus opening, white arrow indicates the phasmid sensory pore). F. Tail region, ventral view (white arrowhead indicates the anus). G. Vulva region, left side (white arrowhead indicates the vulvar opening). H. Tail region covered with bacterial lawn 
vulva, then tapering towards anus. Cuticle markedly annulated from the end of the first cephalic annule to the level of the anus. Annuli more evident at level of the cervical region. Annuli at the cervical region of $c a .5 \mu \mathrm{m}$ in width, then increasing their width to $c a$. $10 \mu \mathrm{m}$ at the posterior half of body. Lateral alae absent. Head bearing eight paired labiopapillae arranged as two sub-dorsal pairs and two sub-ventral pairs. Labiopapillae are C-shaped and elevated, with deep center.
Amphids lateral, as crescent-like pores, located at the top of cuticular elevations. Buccal aperture trirradiate, with three hexagonal labia arranged as two sub-dorsal and one ventral. Distal side of each labia present a rounded cleavage that combines as a circular aperture when the three labia are in contact. First cephalic annule cone-like, truncate, barely inflated, ca. 1.5 head-lengths long. Oesophagus consisting of a muscular, cylindrical procorpus, its diameter similar in all its ex-

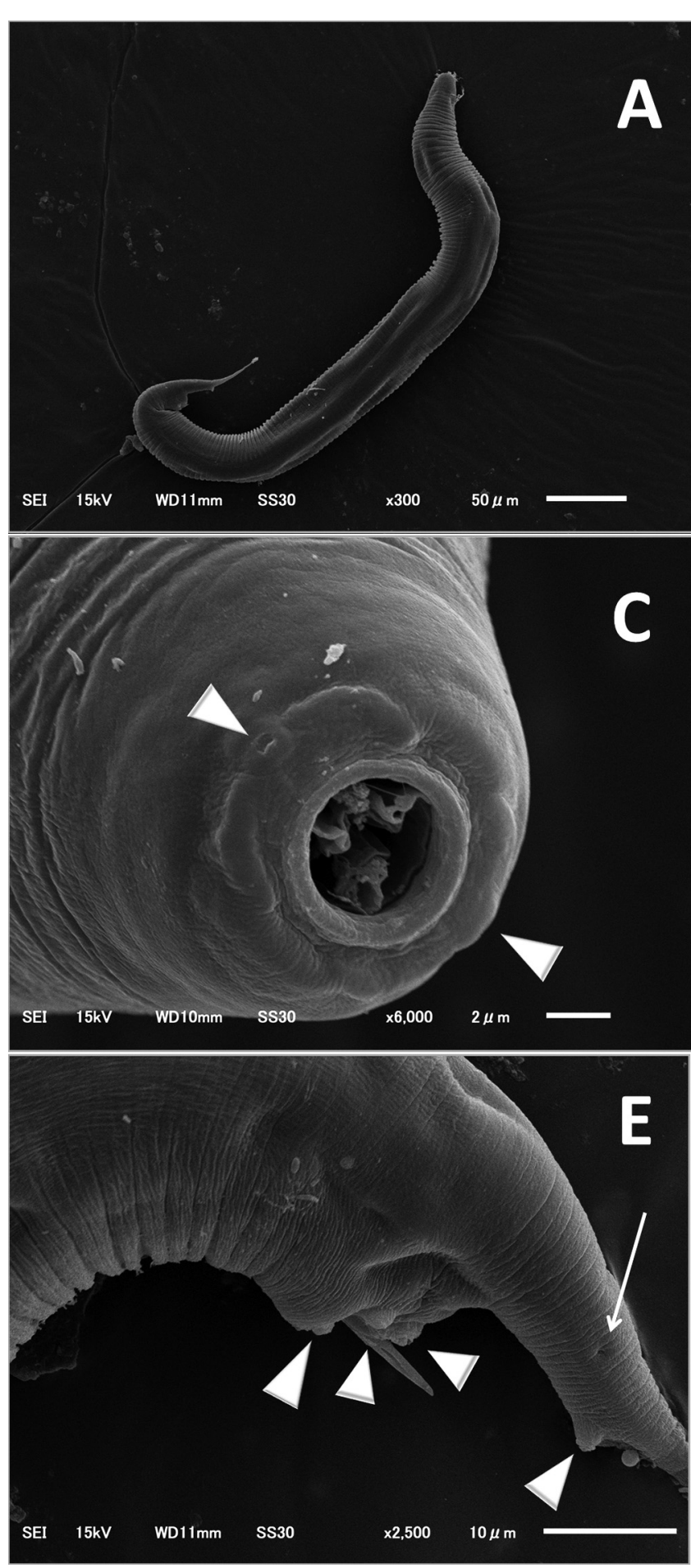

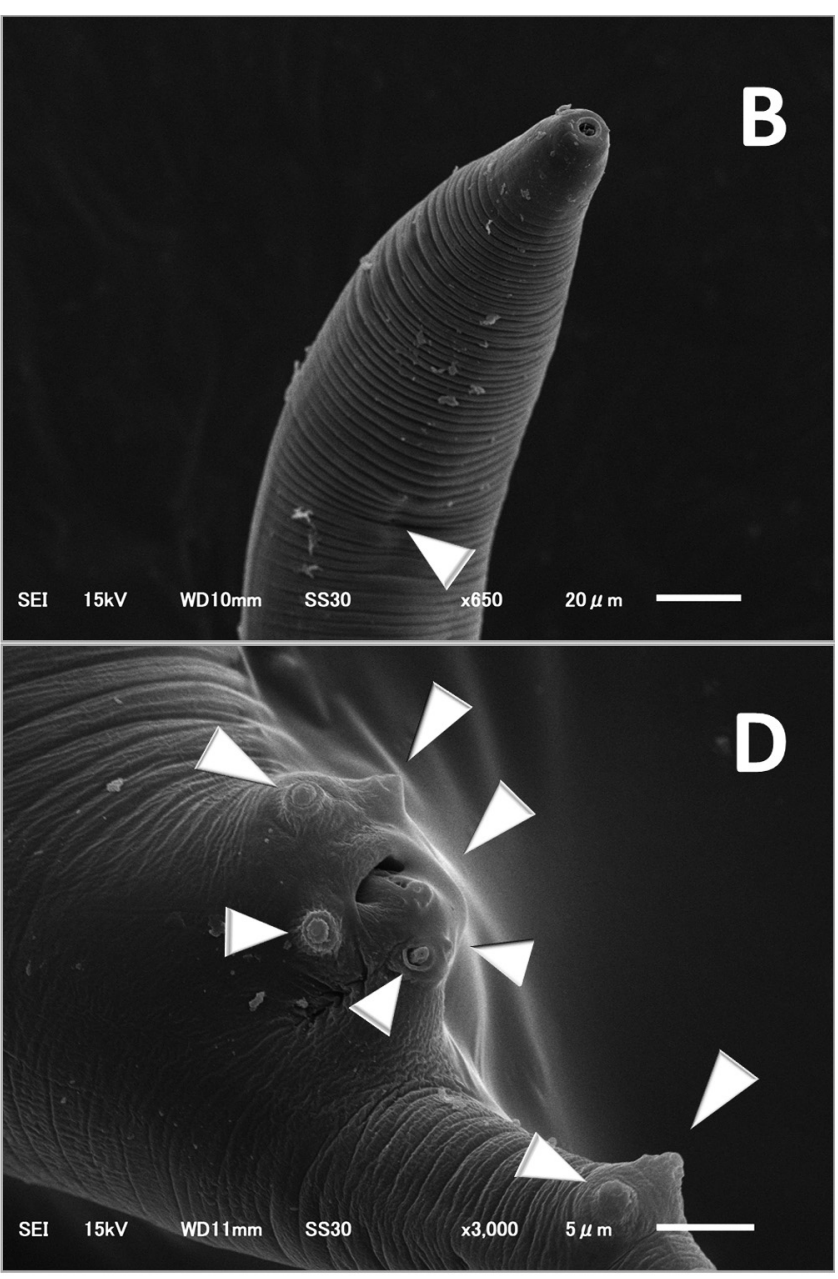

Fig. 4. Thelastoma bulhoesi (de Magalhães, 1900). Male. SEM images. A. Habitus of the adult. B. Cephalic region, front lateral view (white arrowhead indicates excretory pore). C. Anterior end, en face view (white arrowheads indicate the amphidial sensory pore). D. Cloacal region, ventro-lateral view (white arrowheads indicate the caudal papillae). E. Cloacal region, lateral view (white arrowheads indicate the caudal papillae, white arrow indicates the phasmid sensory pore) 
Table I. Morphometrics of Thelastoma bulhoesi (de Magalhães, 1900) (Oxyuridomorpha: Thelastomatidae) from Periplaneta americana (Linnaeus, 1758) (Blattodea: Blattidae) laboratory strain NC from Japan

\begin{tabular}{|c|c|c|}
\hline & Male $(\mu \mathrm{m}, \mathbf{N}=11)$ & Female $(\mu \mathrm{m}, \mathbf{N}=13)$ \\
\hline $\bar{a}$ & $14.1 \pm 0.9(13.0-15.8)$ & $13.7 \pm 2.5(9.7-16.5)$ \\
\hline $\mathrm{b}$ & $4.9 \pm 0.3(4.1-5.2)$ & $6.1 \pm 0.5(5.4-7.0)$ \\
\hline V \% & - & $50.2 \pm 6.0(40.7-64.7)$ \\
\hline Body length & $869.9 \pm 62.1(733.3-938.1)$ & $2715.5 \pm 290.0(2084.5-3251.2)$ \\
\hline Body width & $61.7 \pm 4.8(53.7-68.7)$ & $204.1 \pm 42.9(131.2-270.6)$ \\
\hline Excretory pore-anterior end & $241.1 \pm 32.2(182.1-286.6)$ & $412.2 \pm 54.1(317.6-523.5)$ \\
\hline Nerve ring-anterior end & $115.1 \pm 10.9(104.5-138.8)$ & $199.7 \pm 19.4(176.2-235.8)$ \\
\hline Tail length & $50.4 \pm 11.0(37.3-70.0)$ & $611.8 \pm 85.7(448.8-731.1)$ \\
\hline Vulva-anterior end & - & $1363.3 \pm 213.1(1042.3-1742.3)$ \\
\hline Buccal cavity length & $6.1 \pm 2.1(3.0-10.5)$ & $16.3 \pm 2.5(11.9-20.9)$ \\
\hline Basal bulb length & $36.8 \pm 3.5(31.4-40.3)$ & $87.1 \pm 7.6(68.7-98.5)$ \\
\hline Basal bulb width & $33.4 \pm 2.4(29.9-37.3)$ & $92.4 \pm 8.3(74.6-104.5)$ \\
\hline Spicule length & $35.1 \pm 2.3(31.4-38.8)$ & - \\
\hline Egg length $(\mathrm{N}=13)$ & - & $85.2 \pm 1.7(83.4-89.0)$ \\
\hline Egg width $(\mathrm{N}=13)$ & - & $65.7 \pm 1.7(62.6-69.5)$ \\
\hline
\end{tabular}

tension. Isthmus short, slightly slender than the procorpus. Basal bulb rounded, valve-plate well developed. Nerve ring encircling procorpus at about its midpoint. Excretory pore located at $c a$. the midpoint of the basal bulb. Intestine simple, sub-rectilinear, its fore region notably inflated, then diminishing until reach a uniform diameter towards its junction with the rectum. Rectum short, anus not prominent. Vulva a ventral, median transverse slit, near the midbody, its lips slightly

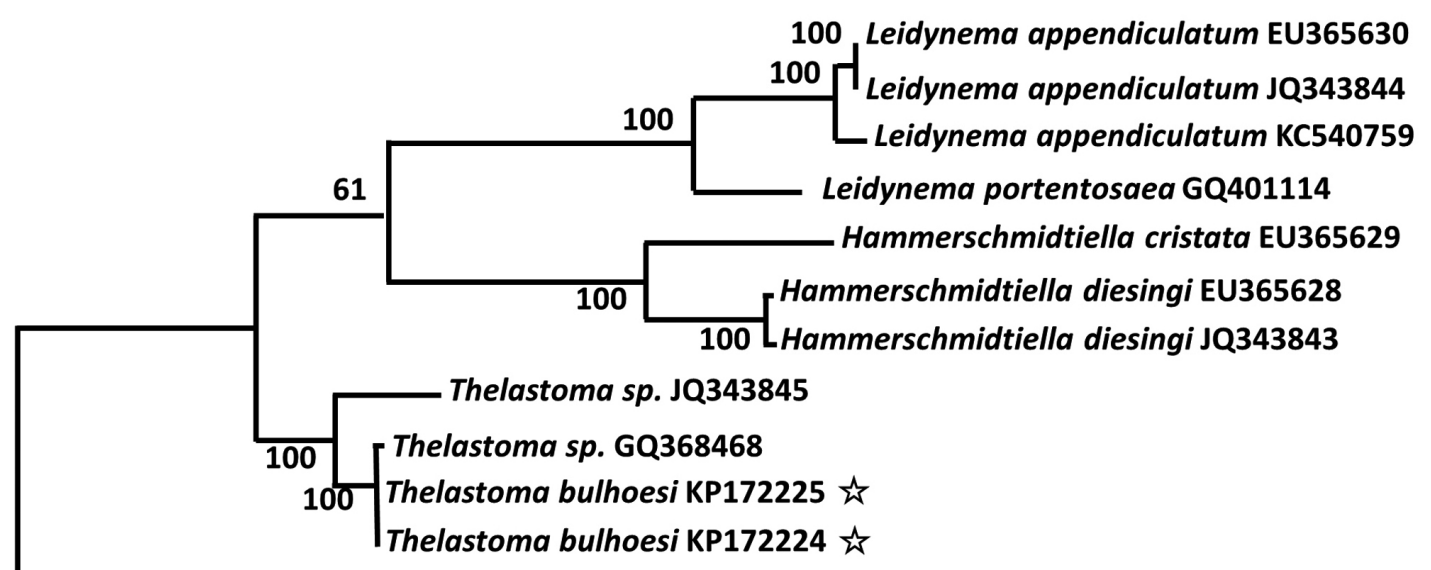

Ascaris lumbricoides AY210806

\subsection{5}

Fig. 5. Phylogenetic position of Thelastoma bulhoesi (de Magalhães, 1900) isolated from Periplaneta americana (Linnaeus, 1758) from both laboratory and field strains. Phylogeny tree was constructed from evolutionary distances using the Neighbor-Joining (NJ) method (Saitou and Nei 1987) and Kimura's two-parameter model (Kimura 1980) with a gamma distribution, using the Mega 5.0 software (Tamura et al. 2011). Ascaris lumbricoides AY210806 was selected as outgroup in the analysis. Star marks indicate nematodes analyzed in this experiment. NCBI GenBank accession numbers: KP172224 for T. bulhoesi NC KHA441 isolated from laboratory strain NC; KP172225 for T. bulhoesi Ishigaki KHA442 isolated from a wild specimen collected in Ishigaki, Okinawa prefecture, Japan 
prominent. Anterior lip of vulva more prominent than posterior. Vagina muscular, anteriorly directed. Genital tract didelphic-amphidelphic. Oöcytes in single rows. Anterior ovary reflexed just behind the fore dilation of the intestine, partially surrounding it. Posterior ovary reflexed or not, almost reaching the base of tail. Eggs spherical to slightly ellipsoidal, shell smooth, thin. Tail subulate, filiform, ending in a fine tip. Phasmids pore-like, lateral, located in the tail, $c a$. $70 \mu \mathrm{m}$ posterior to anus ( $c a$. one fifth of the tail length).

Male. Body shorter and comparatively slender than females. Posterior end ventrally curved. Lateral alae absent. Bluntly rounded anterior end. Cephalic cap with smooth cuticle, without distinctive papillar structures. Posterior to the cephalic cap the cuticle is annulated until $c a$. the level of the genital cone, first cuticular annule at $c a .13 \mu \mathrm{m}$ of the cephalic end. Amphids lateral, as crescent-like pores. Oral opening broad, circular, its diameter $c a .4 \mu \mathrm{m}$, surrounded by a prominent cuticular ring. Stoma short, with three cuticularized plates, one dorsal and two sub-ventral projecting from the stoma wall to the center of the lumen. Oesophagus with a muscular, sub-cylindrical procorpus, diminishing gradually its diameter toward its posterior half until equaling the diameter of the short isthmus. Basal bulb rounded, valve-plate well developed. Cardias not present. Nerve ring encircling procorpus at its posterior half, $c a$. $75 \%$ of its length. Excretory pore located at $c a$. the midpoint of the basal bulb. Intestine simple, its anterior region dilated. Monorchic. Spicule sclerotized, almost straight, proximal tip rounded and distal tip pointed. Cloaca located in an elevated genital cone. Four pairs of copulatory papillae, three of these in the genital cone, arranged as one subventral pre-cloacal pair, one sub-lateral adcloacal pair (similar in size to the first pair) and one smaller, ventral post-cloacal pair. A fourth pair ventral, post-cloacal, located in the first third of the tail filament, which is conical, ending in a fine tip. Phasmids pore-like, lateral, located in the tail filament, $c a$. $5 \mu \mathrm{m}$ anterior to the fourth pair of papil- lae ( $c a$. one third of the distance between the cloaca and such pair of papillae).

\section{Differential diagnosis}

Barus and Koubková (2002) divided the genus Thelastoma in four species groups based on the relative tail length (ratio of tail length/body length) of the females. According to such arrangement, T. bulhoesi is within the group B, which includes species with long tail, filiform, comprising the $25-48 \%$ of the body length (the upper limit always being higher than 30\%). These species are T. gipetiti Van Waerebeke, 1987 (Madagascar and Mali); T. dollfusi Osche, 1960 (Tanzania); T. macracamphidum Christie, 1931 (USA); T. malaysiense Khairul and Paran, 1977 (Malaysia) and T. riveroi Chitwood, 1932 (Cuba, West Indies). T. gueyei Koubková, Barus, Matejusová, Hodová and Koubek, 2006 (Senegal) is posterior to the arrangement of Barus and Koubková (2002) and also correspond to group B.

$T$. riveroi is the more similar species to T. bulhoesi in both, morphology and biometrics. The more evident feature for segregate females of $T$. bulhoesi from $T$. riveroi is the presence of smooth-shelled eggs in the former in opposition to eggs with a characteristic thickened groove in the shell in $T$. riveroi (Chitwood 1932).

T. bulhoesi present females with a body longer than T. dollfusi (total length $=2084.5-3251.2 \mu \mathrm{m} v s .1730 .0-1830.0 \mu \mathrm{m}$ ). Moreover, the excretory pore is located more anteriorly in T. dollfusi: at level of the junction of the basal bulb with the isthmus (Osche 1960), instead of T. bulhoesi, with the excretory pore at $c a$. the midpoint of the basal bulb. T. gipetiti and T. gueyei (two species similar in morphology) have the vulva displaced to the posterior third of body $(\mathrm{V} \%=77.0-79.7$ and 75.2-85.8, respectively) vs. T. bulhoesi, that present the vulva at level of midbody (V\%= 40.7-64.7) (Van Waerebeke 1987; Koubková et al. 2006). T. macracamphidum can be segregate from $T$. bulhoesi by having its tail comparatively longer $(\mathrm{c}=2.1-3.2$ vs. 3.6-6.5). The nerve ring is slightly displaced

Table II. Pairwise differences (\%) in the D2/D3 expansion segment of 28S ribosomal RNA gene between seven samples of species of the genus Thelastoma Leidy, 1849 and Hammerschmidtiella Chitwood, 1932 (Nematoda: Thelastomatidae)

1.

1. T. bulhoesi KP172224

2. T. bulhoesi KP172225

3. Thelastoma sp. GQ368468

4. Thelastoma sp. JQ343845

5. H. diesingi EU365628

6. H. diesingi JQ343843

7. H. cristata EU365629
2.

3.

4.

5.

6.

7.

\footnotetext{
Bold numbers highlight the combinations those differences were less than 1 percent
} 
to the posterior half of the corpus (ca. $66 \%$ of its length) in T. macracamphidum (Christie 1931) instead of T. bulhoesi which nerve ring encircles the corpus at its midpoint.

Males are known for all the species of the group excepting $T$. dollfusi. T. malaysiense clearly differs from T. bulhoesi by having the tail comparatively longer: $c a$. one third of the body length (Khairul and Paran 1977) instead the notably shorter tail of $T$. bulhoesi $(\mathrm{c}=11.7-23.3 \mu \mathrm{m})$. Males of T. bulhoesi can be differentiated from T. gipetiti, $T$. gueyei and T. macracamphidum by having spicules with the distal end pointed $v s$. rounded. Besides, males of T. bulhoesi lack of lateral alae, which are present in the other three species. In T. gipetiti the extension of lateral alae is not mentioned in the description, but according to drawings, these structures end at level of the proximal tip of spicule. As in the latter, the extension of lateral alae in T. macracamphidum is not referred in the original description. In T. gueyei the lateral alae extend from about the midpoint of corpus to the level of the first pair of copulatory papillae (Koubková et al. 2006). In addition, in T. macracamphidum, the nerve ring is located at the junction of the corpus with the isthmus in opposition to T. bulhoesi where the nerve ring is located at $c a$. $75 \%$ of the corpus length.

\section{Phylogenetic relation of the nematodes}

Representative adult female individuals of $T$. bulhoesi isolated from $P$. americana lab strain NC and field-captured individual were used for sequencing of the D2/D3 expansion segment of $28 \mathrm{~S}$ ribosomal RNA gene. Genes were sequenced and deposited in the NCBI GenBank with accession number KP172224 for T. bulhoesi NC KHA441 isolated from $P$. americana lab strain NC, and KP172225 for T. bulhoesi Ishigaki KHA442 isolated from a P. americana field individual.

Two sequences data from unknown Thelastoma species isolated from P. americana from Russia (GQ368468) and Argentina (JQ343845) were included in the study. The two Japanese T. bulhoesi formed a well-defined clade with the two Thelastoma sp., being closer to the Russian; scores for the differences between these two segments were 0.2 and $0.5 \%$ (Table II). The NJ inferred tree for thelastomatid species is
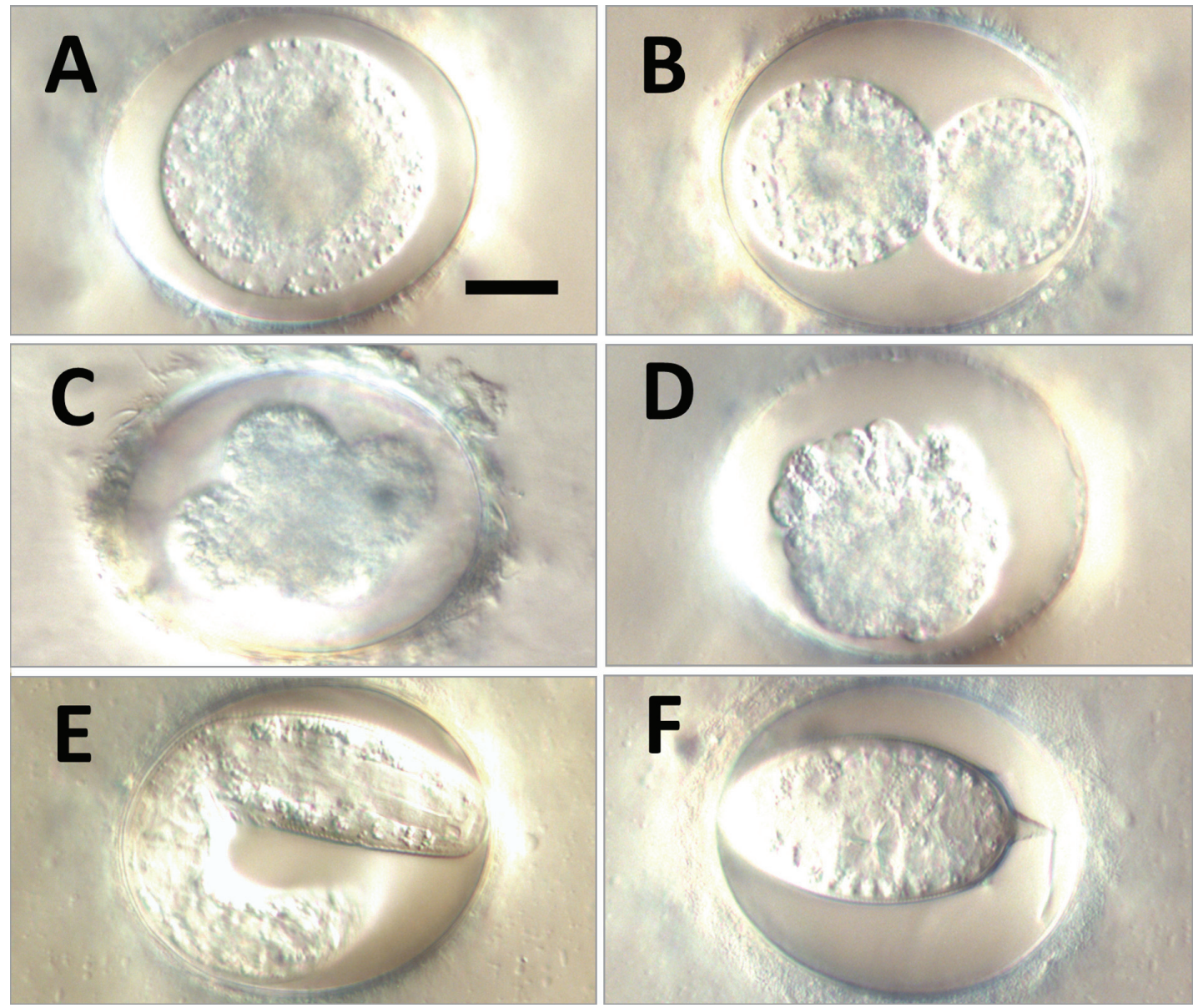

Fig. 6. Different stages of the embryogenesis of Thelastoma bulhoesi (de Magalhães, 1900). Nomarski DIC images. A. 1-cell stage embryo. B. 2-cell stage embryo. C. 4-cell stage embryo. D. Many-cell stage embryo. E. L1 stage. F. L2 stage. Scale bar $20 \mu \mathrm{m}$ 


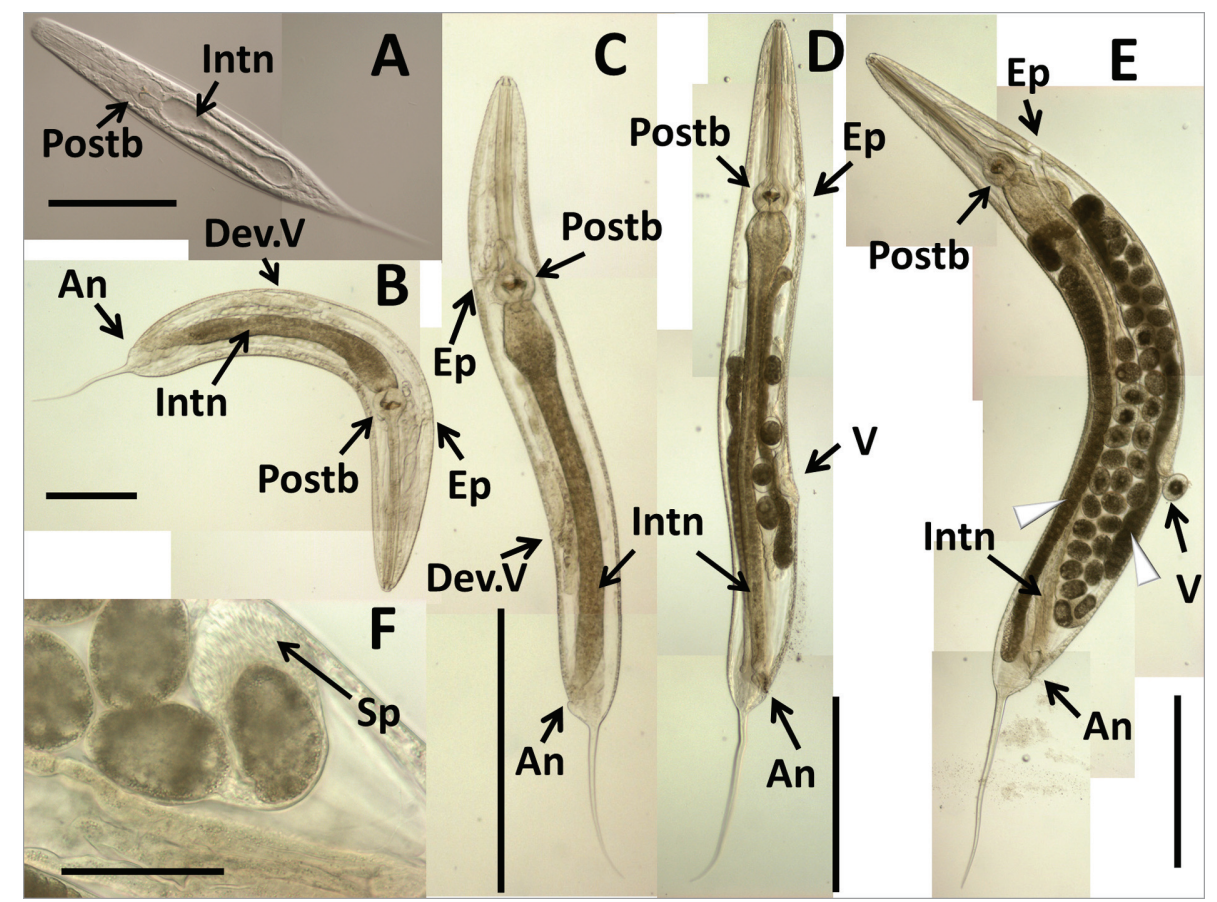

Fig. 7. Different postembryonic stages of Thelastoma bulhoesi (de Magalhães, 1900). Female. Nomarski DIC images. A. Larva $1^{\text {st }}$ day after inoculation, ventral view. B. Larva $14^{\text {th }}$ day after infection, lateral view. C. Larva $21^{\text {st }}$ day after infection, lateral view. D. Young adult female, $31^{\text {st }}$ day after infection, lateral view. E. Mature adult female, $31^{\text {st }}$ day after infection, lateral view (white arrowheads indicate gonads, one egg was oviposited from vulva). F. Eggs in the oviduct and spermatheca in adult female, $31^{\text {st }}$ day after infection. Spermatheca is filled with sperm. Scale bars A, F $100 \mu \mathrm{m}$. B $200 \mu \mathrm{m}$. C, D, E $500 \mu \mathrm{m}$. Abbreviations: Postb, posterior bulb; Intn, intestine; Dev.V., developing vulva; V, vulva; $\mathrm{Ep}$, excretory pore; An, anus; Sp, sperm in the spermatheca

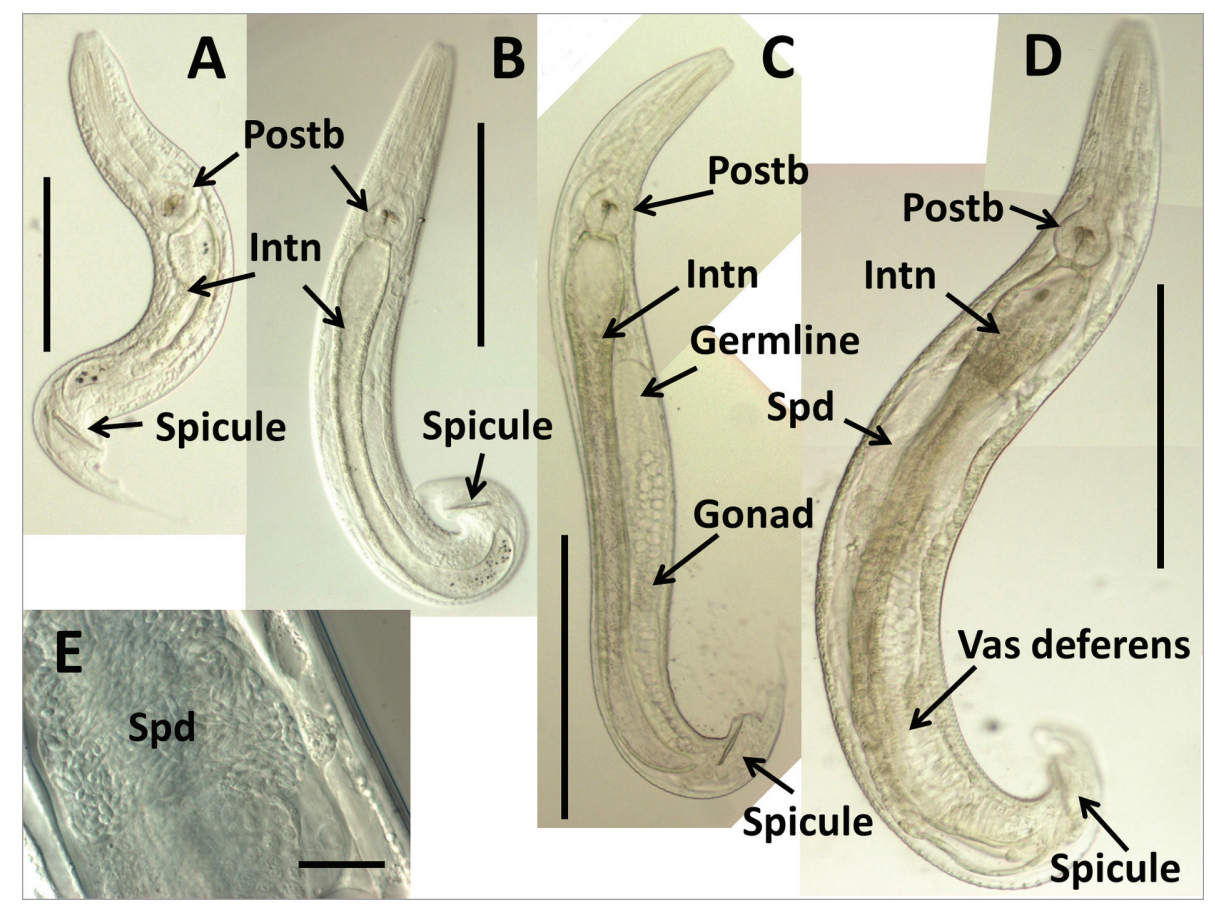

Fig. 8. Different postembryonic stages of Thelastoma bulhoesi (de Magalhães, 1900). Male. Nomarski DIC images. A. Larva $7^{\text {th }}$ day after inoculation, lateral view. B. Larva $14^{\text {th }}$ day after infection, lateral view. C. Larva $21^{\text {st }}$ day after infection, lateral view. D. Adult male, $31^{\text {st }}$ day after infection, lateral view. E. Spermatid in the seminal vesicle in adult male, $31^{\text {st }}$ day after infection. Scale bars A $100 \mu \mathrm{m}$. B, C, D $200 \mu \mathrm{m}$. E $20 \mu \mathrm{m}$. Abbreviations: Postb, posterior bulb; Intn, intestine; Spd, spermatid 
reported in Fig. 5. The two taxa Leidynema and Hammerschmidtiella formed different clades (Fig. 5).

\section{Embryogenesis}

Huge number of shell-formed eggs was observed in the mature female uterus and all were 1-cell stage. (Figs. 6A). Pronuclein or their fusion was not observed during 1-cell stage (Fig. 6A). Then, the embryo divided unequally to form a larger cell and a smaller cell to form a 2-cell stage (Fig. $6 \mathrm{~B})$. Next, the larger cell divided equally followed by the smaller cell to form a rhomboidal 4-cell stage (Fig. 6C). Nuclear membrane was not clearly visible, but one nucleus appeared in a blastomere of the 2- and 4-cell stage embryos. Blastomere number then increased via repeated cell division (Fig.6D), followed by elongation and twitching (i.e. morphogenesis and organogenesis period). Subsequently, the pharynx and basal bulb became clearly visible, marking the beginning of the L1 stage (Fig. 6E). The active vermiform L1 stage embryo then molted to become a balloon-shaped resting L2 stage (Fig. 6F). All embryos that we observed were confirmed to reach the L2 resting stage successfully. It took $6.1 \pm 3.6$ hours from 1-cell stage embryo to 2-cell stage, 9.6 \pm 2.9 hours to 4 -cell stage, $2.5 \pm 0.8$ days to L1 stage, and $6.1 \pm 1.7$ days to L2 stage.

\section{Postembryonic development}

As many thelastomatid nematodes, T. bulhoesi molted from L1 to L2 infection stage within an egg during embryonic development (Todd 1944; McCallister and Schmidt 1984).

After one to three days of infection, few nematode larvae appeared in the cockroach hindgut; their intestinal tract was wide and empty, primordium germ cell was not clearly observed and lateral alae expand from cephalic to caudal region (Fig. 7A). Differences of male/female morphology are not evident at these larval stages. A few numbers of the resting stageformed nematode without eggshell were also seen in the cockroach midgut (data not shown). After seven days of infection, we detected that some nematodes were molting. After this molting, morphological differences between male and female appeared clearly: spicule, and copulatory apparatus appeared in male hook-shaped tail that resembles that of adult males (Fig. 8A). Many male larvae were detected at a same time in individual cockroach hosts at this stage.

After 14 days of infection, sexual dimorphism became prominent. In female, body size was bigger than male, tail shape was long and filiform, the germline was expanding from developing vulva. Well differentiated brown-colored intestine and excretory pore were clearly observed (Fig. 7B). In male, germline was developing and expanding from cloaca (Fig. $8 \mathrm{~B})$. At this time, approximately three females were observed but only one male was seen.

After 21 days of infection, some female having small uterus and externally-opened vulva appeared, but their germ cells were immature (Fig. 7C). Male reproductive system was developed prominently; germline and somatic gonad were visible without evident spermatids (Fig. 8C).

After 31 and 41 days of infection, male and female had reached adulthood. In young adult female, two germlines expand anterior- and posteriorly, and a few shell-formed eggs were in the uterus (Fig. 7D). Body size still continued increasing as well as other organs (Fig. 7E). Two spermatheca were filled with many sperm (Fig. 7F). Adult male body size was far smaller than the female (Fig. 8D). Mature spermatids were present in joint region of the germ lines and somatic gonad (Fig. 8E).

\section{Discussion}

Of the Thelastoma species belonging to group B (Barus and Koubková 2002), T. bulhoesi, T. malaysiense and T. riveroi are recorded parasitizing $P$. americana. The other species are reported from African millipedes (T. gipetiti, T. gueyei and T. dollfusi) and North American scarabaeid beetles (T. macracamphidum). The three species from $P$. americana are morphologically very similar. There are no marked differences between males of T. bulhoesi and T. riveroi, as well as between females of T. bulhoesi and T. malaysiense. In order to clarify this issues, revision of types of these species as well as the collection of new material for SEM and molecular studies would be advisable.

Since the universal primers (Nunn 1992) have been used widely in the thelastomatid nematode (Ozawa et al. 2014; Blanco et al. 2012; Spiridonov and Guzeeva 2009; Jex et al. 2006), rRNA LSU domain is a useful marker for confirmation of the phylogenetic position in this taxa. Two molecular data of unidentified Thelastoma species isolated from P. americana were currently available from GenBank: one was from Argentina (JQ343845) (Blanco et al. 2012) and the other was from Russia (GQ368468). From our phylogeny analysis with the rRNA gene sequence, Thelastoma sp. isolated in Russia is clustered into our Japanese T. bulhoesi, suggesting that they might also be the same species. On the other hand, Thelastoma sp. isolated in Argentina is outside that group and possibly belongs to a different species. Morphology and molecular information of this nematode presented in this paper will become an important basis for understanding of the parasitic nematodes belonging to the genus Thelastoma.

Since embryonic stage is the only period to leave from a host cockroach among the obligate parasitic ecology of the thelastomatid nematodes, we could easily trace the embryogenesis pattern and timing (Ozawa et al. 2014). Embryonic development of $T$. bulhoesi does not progress normally below $15^{\circ} \mathrm{C}$ and at $35^{\circ} \mathrm{C}$, and over $90 \%$ of embryo became L2 resting stage after 128 hours at $25^{\circ} \mathrm{C}$ (about 5.3 days) (McCallister and Schmidt 1984). In our experiment, developmental timing of T. bulhoesi embryo from 1-cell stage to L2 resting stage takes $6.1 \pm 1.7$ days at around $25^{\circ} \mathrm{C}$. 
Because pronuclear appearance and behavior in T. bulhoesi 1-cell embryo were not clearly visible under the DIC microscope (Fig. 6), unlike L. appendiculatum and other nematodes including Bursaphelenchus xylophilus (Steiner and Buhrer, 1934), B. okinawaensis Kanzaki, Maehara, Aikawa and Togashi, 2008, Caenorhabditis elegans (Maupas, 1900), Aphelenchoides besseyi Christie, 1942 (Ozawa et al. 2014; Shinya et al. 2014; Yoshida et al. 2009; Hasegawa et al. 2006), it remains unperceived their reproductive process and sex determination systems. Since Oxyurida nematode reproduces by haplodiploidy (Ainsworth 1991), we then have to use different approach to determine the reproductive mode and sex determination system of $T$. bulhoesi.

T. bulhoesi embryo never hatched on the agar pad nor in the Cockroach Ringer's solution, but T. bulhoesi larvae immediately hatched and changed from the balloon-shape to the vermiform within a day after inoculation (Fig. 7A). L2 resting stage embryos of $L$. appendiculatum and $H$. diesingi were reported to start the second molt and became active elongated-shape in the eggshell after being treated with protein dilute solution (Todd 1944). McCallister and Schmidt (1981, 1983 and 1984) also reported L2 resting stage larva hatched in cockroach hindgut and immediately molt to L3 larva, but there was no basic information for determining the developmental stage. T. bulhoesi isolated one- and threeday after inoculation had lateral alae expand from cephalic to caudal region (Fig. 7A). We could see such prominent alae only at this stage. This is not considered cuticle molting because nematodes started to feed at this stage and their food fragments were seen in the intestinal lumen. We predicted that the nematode did not molt during this stage but just extended their body to become vermiform after hatching. We could detect nematode molting after 7 days, and after this event clear male/female dimorphism appeared (Fig. 8A). Male genital structure appeared after this molting but germ cells were immature (Fig. 8A), and such developmental feature seems to be widely common in thelastomatid nematodes (Zervos 1983).

Many male and female larvae were detected at a same time in individual cockroach hosts at this stage (after seven days of infection), but male population decreased to just one individual after 14 days of infection. Such male population control was also observed in L. appendiculatum parasitizing P. americana (Hominick and Davey 1972) and in P. fuliginosa (Ozawa et al. 2014), and in Protrellus dixoni parasitizing Drymaplaneta variegata (Zervos, 1988). From this stage, sexual dimorphism of T. bulhoesi appeared, and also some unknown cue started to regulate male population, perhaps all of the male except for the one might be discharged to the outside of the host body.

Acknowledgements. The American cockroach was provided by Nissan Chemical Co. Ltd., Saitama, Japan. We thank Dr. Rina Sriwati for technical assistance and valuable advice. This work was supported by the research fund from Institute of the Biological Function, Chubu University (to KH), and JSPS Research Fellowship for Young Scientists (to $\mathrm{SO}$ ).

\section{References}

Adamson M.L., Clease D.F. 1989. Morphological changes during in ovo development in the Thelastomatoidea: description and functional considerations. Journal of Parasitology, 75, 728-734

Adamson M.L., Noble S.J. 1993. Interspecific and intraspecific competition among pinworms in the hindgut of Periplaneta americana. Journal of Parasitology, 79, 50-56

Adamson M.L., Van Waerebeke D. 1992. Revision of the Thelastomatoidea, Oxyurida of invertebrate hosts I. Thelastomatidae. Systematic Parasitology, 21, 21-63

Ainsworth R. 1991. Cytogenetic evidence of haplodiploidy in two species of nematode (Pharyngodonidae: Oxyurida) from New Zealand lizards. Journal of Parasitology, 77, 92-98

Appel A.G., Smith L.M.II. 2002. Biology and management of the smokybrown cockroach. Annual Reviews of Entomology, 47, 33-55. DOI: 10.1146/annurev.ento.47.091201.145106

Barus V., Koubková B. 2002. The first species of Thelastoma Leidy, 1849 (Nematoda: Thelastomatidae) parasitising the scorpion Euscorpius italicus (Chactidae: Scorpionidea). Systematic Parasitology, 53, 141-146

Bell W.J. (Ed.) 1981. The Laboratory Cockroach - Experiments in Cockroach Anatomy, Physiology and Behavior. Chapman \& Hall, London, UK, pp.161

Bell W.J., Adiyodi K.G. 1981. The American Cockroach. Chapman and Hall, London, pp.529

Bell W.J., Roth L.M., Nalepa C.A. (Eds.) 2007. Cockroaches: ecology, behavior, and natural history. The Johns Hopkins University Press, Baltimore, Maryland, USA, pp. 230

Biswas P.K., Chakravarty G.K 1963. The systematic studies of the zoo-parasitic oxyuroid nematodes. Zeitschrift für Parasitenkunde, 23, 411-428

Blanco M.V., Lax P., Dueñas J.C.R., Gardenal C.N., Doucet M.E. 2012. Morphological and molecular characterization of the entomoparasitic nematode Hammerschmidtiella diesingi $(\mathrm{Ne}-$ matoda, Oxyurida, Thelastomatidae). Acta Parasitologica, 57, 302-310. DOI: 10.2478/s11686-012-0029-2

Camino N.B., Ricuzzi M., Costa L.L. 2013. A new Thelastomatidae, Hammerschmidtiella laplate $\mathrm{n}$. sp. (Nematoda) parasite of the cockroach Periplaneta americana (L.) (Blattodea, Blattidae) from Argentina. Neotropical Helminthology, 7, 96-103

Chaudhary A., Kansal G., Singh N., Singh H. S. 2014. New molecular data for parasite Hammerschmidtiella indicus and Thelandros scleratus (Nematoda; Oxyurida) to infer phylogenetic position. Turkish Journal of Zoology, 38, 1-5. DOI:10. 3906/zoo-1311-18

Christie J.R. 1931. Some nemic parasites (Oxyuridae) of coleopterous larvae. Journal of Agricultural Research, 42, 463-482

Chilton N.B., Gasser R.B., Beveridge I. 1995. Differences in a ribosomal DNA sequence of morphologically indistinguishable species within the Hypodontus macropi complex (Nematoda: Strongyloidea). International Journal for Parasitology, 25, 647-651

Chitwood B.G. 1932. A synopsis of the nematodes parasitic in insects of the family Blattidae. Zeitschrift für ParasitenKunde, 5, 14-50

Connor S., Adamson M. 1998. Niche overlap among three species of pinworm parasitic in the hindgut of the American cockroach, Periplaneta americana. Journal of Parasitology, 84, 245-247.

de Magalhães P.S. 1900. Notes d'Helminthologie Brésilienne. Archives de Parasitologie, 3, 34-69. (in French)

Dollfus R.P. 1952. Quelques Oxyuroidea de Myriapodes. Annales de Parasitologie Humaine et Comparée, 27, 143-236. (in French)

Dobrovolny C.G., Ackert J.E. 1934. The life history of Leidynema appendiculatum (Leidy), a nematode parasite of cockroaches. Parasitology, 26, 468-480 
Felsenstein J. 1985. Confidence limits on phylogenies: An approach using the bootstrap. Evolution, 39, 783-791

Groschaft J. 1956. Studies on the Oxyuroidea from cockroaches (Blattodea) in the laboratory. Ceskonslovenska Parasitologie, 3, 67-74 (in Czech)

Hall T.A. 1999. BioEdit: a user-friendly biological sequence alignment editor and analysis program for Windows 95/98/NT. Nucleic Acids Symposium Series, 41, 95-98

Hasegawa K., Mota M.M., Futai K., Miwa J. 2006. Chromosome structure and behavior in Bursaphelenchus xylophilus (Nematoda: Parasitaphelenchidae) germ cells and early embryo. Nematology, 8, 425-434. DOI: 10.1163/156854106778493475

Hominick W.M., Davey K.G. 1972. The influence of host stage and sex upon the size and composition of the population of two species of thelastomatids parasitic in the hindgut of Periplaneta americana. Canadian Journal of Zoology, 50, 947-954

The Japanese Society of Pestology. 2014 Pest distribution record 2014 (In Japanese). Pestology, 29, 62

Jex A.R., Hu M., Rose H.A., Schneider T.H., Cribb T.H., Gasser R.B. 2006. Molecular characterization of Thelastomatoidea (Nematoda: Oxyurida) from cockroaches in Australia. Parasitology, 133, 123-129. DOI: http://dx.doi.org/10.1017/S00311 82006009978

Kimura M.1980. A simple method for estimating evolutionary rate of base substitutions through comparative studies of nucleotide sequences. Journal of Molecular Evolution, 16, 111-120. DOI: 10.1007/BF01731581

Khairul A.A., Paran T.P. 1977. Parasites of Periplaneta americana Linn., in Penang, Malaysia I. Thelastoma malaysiense, new species, with notes on Hammerschmidtiella diesingi and Leidynema appendiculata. Malayan Nature Journal, 30, 69-77

Koubková B., Barus V., Matejusová I., Hodová I., Koubek P. 2006. Thelastoma gueyei sp. n. (Nematoda: Thelastomatidae) from the Senegal diplopod Archispirostreptus tumuliporus (Diplopoda: Spirostreptidae). Nematology, 8, 739-747

McCallister G.L. 1988. The Effect of Thelastoma bulhoesi and Hammerschmidtiella diesingi (Nematoda: Oxyurata) on Host Size and Physiology in Periplaneta americana (Arthropoda: Blattidae). Proceedings of the Helminthological Society of Washington, 55, 12-14

McCallister, G.L. 1993. The Effect of Temperature, pH, Sodium Chloride, and Glucose on the Survival of Female Thelastoma bulhoesi (Nematoda: Oxyurata). Proceedings of the Helminthological Society of Washington, 60, 170-173

McCallister G.L., Schmidt G.D. 1981. Diurnal Migration of the Female of Thelastoma bulhoesi (Oxyurata: Thelastomida) in the American Cockroach, Periplaneta americana. Proceedings of the Helminthological Society of Washington, 48, 127-129

McCallister G. and Schmidt, G.D. 1983. Development of Thelastoma bulhoesi (Oxyurata: Thelastomatida) and the effect of Thiabendazole on the unembryonated egg. Journal of Nematology, 15, 296-301

McCallister G., Schmidt, G.D. 1984. Effect of temperature on the development of Thelastoma bulhoesi (Oxyurata, Thelastomatida) and other nematodes. Journal of Nematology, 16, 355-360

Morffe J., García N. 2010. Hystrignathus dearmasi sp. n. (Oxyurida, Hystrignathidae), first record of a nematode parasitizing a Panamanian Passalidae (Insecta, Coleoptera). Zookeys, 57, 18. DOI: /10.3897/zookeys.57.477

Nedelchev, S., Pilarska, D., Takov, D., Golemansky, V. 2013. Protozoan and Nematode Parasites of the American Coakroach Periplaneta americana (L.) from Bulgaria. Acta Zoologica Bulgarica, 65, 403-408

Nunn G.B. 1992. Nematode molecular evolution. An investigation of evolutionary patterns among nematodes based upon DNA sequences. Ph. D. dissertation. University of Nottingham, UK, pp. 187

Osche G. 1960. Systematische, morphologische uns parasitophyletische Studienanparasitischen Oxyuroidea (Nematoda) exotischer Diplopoden (Ein Beitrag zur Morphologie des Sexualdimorphismus). Zoologische Jahrbücher. Abteilung für Systematik, Oecologie und Geographie der Tiere, 87, 395440. (in German)

Ozawa S., Vicente C.S.L., Sato K., Yoshiga T., Kanzaki N., Hasegawa K. 2014. First report of the nematode Leidynema appendiculata from Periplaneta fuliginosa. Acta Parasitologica, 59, 219-228

Rentz D. (Ed). 2014. A guide to the cockroaches of Australia. CSIRO Publishing, Australia, pp. 318

Ruiz J.M., Coelho E. 1955. Nematóides (Oxyuroidea) parasitos de Diplópodos da Ilha da Queimada Grande, São Paulo, Brasil. Memorias do Instituto Butantan, 27, 51-66. (in Portuguese)

Saitou N., Nei M. 1987. The neighbor-joining method: A new method for reconstructing phylogenetic trees. Molecular Biological Evolution, 4, 406-425

Shah, M.M. 2007. Some studies on insect parasitic nematodes (Oxyurida, Thelastomatoidea, Thelastomatidae) from $\mathrm{Ma}$ nipur, North-East India. Acta Parasitologica, 52, 346-362

Shaham S. 2006. Methods in Cell Biology. In: The C. elegans Research Community (ed.). WormBook, http://www.wormbook.org. DOI: doi/10.1895/wormbook.1.49.1

Shinya R., Hasegawa K., Chen A., Kanzaki N., Sternberg P. 2014. Evidence of hermaphroditism and sex ratio distortion in the fungal feeding nematode Bursaphelenchus okinawaensis. G3Genes Genomes Genetics, 4, 1907-1917. DOI: 10.1534/g3.114.012385

Singh H.S., Kaur H. 1988. On a new nematode, Hammerschmidtiella bisiri n. sp. from Periplaneta americana Linn. Indian Journal of Parasitology, 12, 187-189

Spiridonov S.E., Guzeeva E.A. 2009. Phylogeny of nematodes of the superfamily Thelastomatoidea (Oxyurida) inferred from LSU rDNA sequence. Russian Journal of Nematology, 17, 127134.

Tamura K., Peterson D., Peterson N., Stecher G., Nei M., Kumar S. 2011. MEGA5: Molecular Evolutionary Genetics Analysis using Maximum Likelihood, Evolutionary Distance, and Maximum Parsimony Methods. Molecular Biological Evolution, 28, 2731-2739. DOI: 10.1093/molbev/msr 121

Todd A.C. 1944. On the development and hatching of the eggs of Hammerschmidtiella diesingi and Leidynema appendiculatum, nematodes of roaches. Transactions of the American Microscopical Society, 63, 54-67

Van Waerebeke D. 1987. Description de Thelastoma gipetiti n. sp. parasite de Spirostreptidae et considérations sur le genre Thelastoma Leidy, 1850 (Oxyuroidea; Nematoda). Revue Nématologie, 10, 401-407

Yoshida K., Hasegawa K., Mochiji N., Miwa J. 2009. Early embryogenesis and anterior-posterior axis formation in the whiteip nematode Aphelenchoides besseyi. Journal of Nematology, $41,17-22$

Zervos S. 1983. Blatticola monandros n. sp. (Nematoda: Thelastomatidae) from the blattellid cockroach Parellipsidon pachycercum. New Zealand Journal of Zoology 10, 329-334

Zervos S. 1988. Evidence for population self-regulation, reproductive competition and arrhenotoky in a thelastomatid nematode of cockroaches. Parasitology, 96, 369-379. DOI: http://dx.doi.org/ $10.1017 / \mathrm{S} 0031182000058352$

Received: June 18, 2015

Revised: October 23, 2015

Accepted for publication: November 30, 2015 